\title{
Fuel loading and flammability in the Mediterranean Basin woody species with different post-fire regenerative strategies
}

\author{
S. Saura-Mas ${ }^{1,2}$, S. Paula ${ }^{3}$, J.G. Pausas ${ }^{4}$, F. Lloret $^{1}$ \\ ${ }^{1}$ CREAF (Center for Ecological Research and Forestry Applications) and Unit of Ecology, \\ Department of Animal and Plant Biology and Ecology, Autonomous University of Barcelona, E- \\ 08193 Bellaterra, Barcelona, Spain \\ ${ }^{3}$ CEAM (Fundación Centro de Estudios Ambientales del Mediterráneo), C/ Charles R. Darwin 14, \\ Parc Tecnologic, 46980 Paterna, Valencia, SPAIN \\ ${ }^{4}$ CIDE, CSIC, Camí de la Marjal s/n, Albal, 46470, Valencia, Spain \\ ${ }^{2}$ Author for correspondence, e-mail: s.sauramas@creaf.uab.es
}

\begin{abstract}
The flammability and combustibility of plant communities are determined by species features related to growth-form, structure and physiology. In some ecosystems, such as the Mediterranean ones, these characteristics may contribute to the existence of fire-prone species. Moreover, different post-fire regenerative strategies may present different degrees of recovery, depending on the particular fire regime. Thus, differences in the flammability of species with distinct post-fire regenerative strategies can be the key to the establishment of a mutual link between fire regime and vegetation.

We measured several parameters associated with the flammability and fuel loading of the dominant woody species in shrublands in the western Mediterranean Basin. We then analyzed the differences between these parameters in species with different post-fire regenerative strategies: seeders and non-seeders.

Overall, seeder species show lower fuel load but are more prone to burning due to higher dead-tolive fuel ratio, live fine-fuel proportion and dead fine-fuel proportion. Moreover, they burst into flame at lower temperatures than non-seeders.

In the Mediterranean Basin, most seeder species emerged mainly during the Quaternary, under a highly fluctuating Mediterranean climate and during recurrent fires. We propose that properties related to the combustibility and flammability of seeders may be the result of selective pressures associated with both fire and climate.

These results suggest that ecosystems dominated by seeder species are more susceptible to fire risk than those dominated by non-seeder species in the Mediterranean Basin. Therefore, the proportion of these types of species resulting from previous fire or management history is likely to determine the characteristics of future fire events.
\end{abstract}

\section{Keywords:}

Fire, combustibility, flammability, fuel, Mediterranean Basin, seeder, resprouting.

\section{INTRODUCTION}

Wildfire is an important disturbance in the ecosystems of the Mediterranean Basin and can determine species composition and ecosystem functioning (Whelan 1995; Lloret and Vilà 2003; Eugenio and Lloret 2004; Rodrigo et al. 2004; Bond et al. 2005). In these communities, post-fire regeneration is determined by the different mechanisms exhibited by the species, and there is evidence that the proportions of regenerative types in plant communities may be affected by the fire regime (Bellingham and Sparrow 2000; Franklin et al. 2001; Pausas et al. 2004; Lloret et al. 2005a; Pausas and Bradstock 2007; Pausas and Lloret 2007; Vila et al. 2008). It has also been reported that morphological and physiological features (low moisture content, abundant amount of resins, oils, and volatile products, persistence of dead parts in the canopy, etc...) make many Mediterranean woody species fire-prone (Papió and Trabaud 1991; Bond and Midgley 1995; Schwilk and Ackerly 2001; De Luis et al. 2004; Alessio 2006; Scarff and Westoby 2006). Thus, differences in the flammability of species with different post-fire regenerative strategies can be the 
determinant factors in the dynamics of fire-prone communities by promoting fire-vegetation feedbacks. For instance, a positive feedback may occur if more flammable species also show more successful regenerative trends (Mutch 1970), as has been reported for grasses (Vilà and Lloret 2000; Vilà et al. 2001; Grigulis et al. 2005) and pines (Schwilk and Ackerly 2001).

In the Mediterranean Basin, some preliminary studies show that species with a particular post-fire regenerative strategy (i.e. fire-stimulated germination) consistently exhibit traits that heighten flammability (i.e. lower water content in summer) (Saura-Mas and Lloret 2007). The main post-fire regenerative strategies include that of seeders, propagule-persister species in which the population persists locally in propagule form (seed, fruit) after fire. These are species with populations that regenerate by establishing seedlings promptly after fire from a persistent seed bank (seeds that resist, or are protected, from fire) and the recruitment of new individuals is often enhanced by fire (Pausas et al. 2004). This category includes species that only regenerate after fire from seeds (obligate seeders; R-P+: Pausas et al. 2004) and species that both resprout and establish seedlings after fire (facultative seeders, $\mathrm{R}+\mathrm{P}+$ ). In contrast, non-seeders are species whose propagules (seed, fruit) do not persist after fire; consequently, the propagules owe their existence entirely to dispersal from outside the fire-affected area. Also, some non-seeders may regenerate after fire by resprouting from underground or aerial parts of the plant (obligate resprouters; R+P-). As regards woody plants, seeders are usually species with a relatively short life cycle and a high degree of recruitment after fire, while non-seeders are species with longer life cycles and lower rates of recruitment after fire (Pate et al. 1990; Verdaguer and Ojeda 2002; Pausas et al. 2004; Knox and Clarke 2005; Schwilk and Ackerly 2005). In the Mediterranean Basin, late successional communities are often dominated by non-seeder ( $\left.R+P_{-}\right)$species, while many seeders (R-P+, $\mathrm{R}+\mathrm{P}+$ ) may also recruit after disturbances such as clearing.

Species in our study region with the seeder trait have evolved under the Mediterranean climate established in the Quaternary, while the resprouter attribute exhibited by many non-seeders is an ancestral trait found in many ancient lineages and widely distributed in many ecosystems (Lloret et al. 1999; Verdú 2000; Bond and Midgley 2003; Bond and Keeley 2005). In fact, it is considered that non-seeder species evolved in the Tertiary before the establishment of the Pre-Mediterranean climate (Herrera 1992; Verdú 2000; Pausas and Verdú 2005).

Various determining factors are worthy of consideration with respect to the fuel loading and flammability vegetation traits. Specifically, structural and chemical plant traits are inherent factors in the vegetation cover that determine the combustibility and flammability of the community. The term combustibility is often confused with flammability but, according to Trabaud (1976), flammability in fact includes three components: ignitability, combustibility and sustainability. Ignitability indicates how easily the fuel ignites; combustibility refers to how plants burn after they have been ignited; sustainability registers the stability of the burning rate, i.e., how well the fuel continues to burn.

A number of elements affect species flammability: the amount of heat received, the distribution and size of live and dry organs (branches, leaves), the chemical composition and the water content (Trabaud 1989; Philpot 1970; Cornelissen et al. 2003). Specifically, tissue moisture and organ morphology (i.e. surface to volume ratio) are essential as they determine, respectively, the amount of energy needed to start the fire reaction and the contact between the reagents (fuel and the atmospheric oxygen) (Papió 1994; Massari and Leopaldi 1995; Dimitrakopoulos and Panov 2001; Ralph 2001).

Combustibility is determined by fuel load and fuel characteristics such as the proportion of live and dead material or the amount of fine and coarse materials. Standing dead branches can increase fire temperatures and heat release (Schwilk 2003) and the dead fine-fuel ratio is an effective indicator of fire danger (Bond and Van Wilgen 1996; De Luis et al. 2004). In fact, many fire-risk prevention and extinction programs are based on information about fuel-loading properties (Valette et al. 1994; Pons and Vayreda 1996; Viegas et al. 2001).

In this study, we investigate the relationship between flammability, fuel loading and post-fire regenerative traits according to the following hypotheses: (1) species with post-fire recruitment 
(seeders) may have obtained selective advantage as a result of fire occurrence, and would show more flammable traits, and (2) seeder species in the Mediterranean Basin have evolved traits associated with water-deficit tolerance (i. e. low leaf moisture) that also promote fire occurrence. We also consider some variables that influence flammability, such as leaf morphology (surface to volume ratio) and leaf moisture. When comparing the different types of species, we also accounted for the weight of taxonomical linkage between them. We endorse these hypotheses as they are consistent with the proposition that fire acts as a selective force promoting the obligate seeder strategy, which would take advantage of the competition-free conditions found after wildfires (Zedler 1995; Bond and Van Wilgen 1996; Lloret 1998; Schwilk and Ackerly 2001; Pausas et al. 2003).

The main objective of this study is to explore the flammability and the fuel loading of species showing different post-fire regenerative strategies in shrublands in the Western Mediterranean Basin.

\section{MATERIALS AND METHODS \\ Study areas and species}

This study was conducted in two separate locations sharing structural and compositional features in the eastern coastal mountains of the Iberian Peninsula. This approach reinforces the consistency of common patterns and accounts for the variability of flammability traits. One site was located in the Massís del Montgrí (hereafter, Montgrí), in the northeast Iberian Peninsula (42 $12^{\circ}$ ' N, $\left.3^{\circ} 24^{\prime} \mathrm{W}\right)$, and the second was located in the Serra de la Murta (hereafter, Murta) $\left(39^{\circ} 4^{\prime} \mathrm{N}, 0^{\circ} 12^{\prime}\right.$ W), $420 \mathrm{~km}$ south of the Montgrí site. In both areas, vegetation was dominated by open pine woodlands and coastal shrublands. The sampling was conducted on shrublands (1-2 $\mathrm{m}$ high) growing on limestone that had not been affected by wildfire for over 10 years.

Both sites have cool winters and warm summers (mean annual temperature is $14.8^{\circ} \mathrm{C}$ in Montgrí and $17.4{ }^{\circ} \mathrm{C}$ in Murta), but Murta presents lower summer precipitation and higher summer temperatures (49.3 mm of rainfall from June to August and mean temperatures of $25.7^{\circ} \mathrm{C}$ in the hottest month [August]) than Montgrí (113 mm of rainfall from June to August and mean temperatures of $22.4^{\circ} \mathrm{C}$ in the hottest month [August]), indicating higher water evapo-transpiration and greater water demand on the southern site (Murta) (Pérez 1994, Ninyerola et al. 2000 and Ninyerola et al 2003).

We sampled the dominant woody species of the studied shrubland communities (29 species covering all the sites and experiments; Bolòs et al. 2005), including data on different life-forms and post-fire regenerative strategies across a broad taxonomical range (Table 1). In order to obtain comparable results between regenerative strategies, we excluded some life-forms, such as pine trees and herbs (for instance, grasses), that are also found on these shrublands but show very different structural features. Other tree species, such as Quercus ilex and Olea europaea, often remain as shrubs in these communities. Species were classified into two regenerative groups, according to their post-fire regenerative strategies: seeders and non-seeders. For this classification, we considered the published information (Cucó 1987; Papió 1988; Lloret and Vilà 1997; Verdú 2000; Alberdi and Cavero 2003; Lloret and Vilà 2003; Paula et al. 2009), and direct field observations from a recently burnt area in Montgrí. Species that are able to both recruit seedlings and resprout after fire were categorized as seeders. This grouping is based on previous studies that have shown that these species exhibit a water-use strategy more similar to that of seeders than to that of species that can only resprout after fire (Saura-Mas and Lloret 2007).

\section{Fuel loading}

Sampling was carried out in summer (July to August) 2006, in five non-senescent, fully developed and healthy adult individuals per species in each of the study areas. To describe fuel-loading traits, we sampled 15 species that were present on both study sites with additional five species in Montgrí and one in Murta (Table 1). These additional species were not considered for the comparison between the sites. Sampled individuals of the same species were growing under similar conditions outside the tree canopy. Each individual was cut at the surface of the ground. 
Dead and live fuel fractions were separated in situ and weighed (fresh weight, fw). Shoots of both dead and live material, including branches and logs, were separated in the laboratory according to two diameter classifications (fine fuel: $\varnothing<6 \mathrm{~mm}$; coarse fuel: $\varnothing>6 \mathrm{~mm}$ ). Leaves of live material were considered as a separate fraction. Finally, the classified material was oven-dried ( 3 days at $60^{\circ} \mathrm{C}$ ) to obtain its dry weight.

\section{Flammability}

We sampled 15 species that were present in both study sites, plus five and one additional species in Montgrí and Murta, respectively (Table 1). Leaf samples from five to ten individuals (replicates) from each species were collected on each site. In some cases, the species considered in the fuelload measurements could not be used in the flammability test because of their very small leaf size and their consequent small total leaf biomass per plant. Some species that were not considered in the fuel load estimations were, however, included in the flammability test (see Table 1).

Leaf samples were collected in August 2006, the month of the year with the highest fire hazard in the studied areas. We homogenized the samples by basing them only on leaves, avoiding any mixtures with shoots that show very different structural properties. Moreover, leaves tend to have a higher surface to volume ratio, and therefore greater flammability, and are thus a good indicator of plant flammability (Cornelissen et al. 2003). Leaf samples were harvested from branches exposed to direct sunlight in well-grown plants established under similar conditions. They were fully expanded leaves, free of any herbivore or pathogen damage. The number of leaves sampled from each individual varied according to the size and weight of the leaves from each species.

The material from each plant was enclosed in a hermetic plastic bag and stored under ice-box conditions to avoid water loss during transportation from the field and in the laboratory (Viegas et al. 2001), where we separated leaves from twigs. A sub-sample of leaves was used from each plant to estimate the leaf moisture (LM) at the time of flammability. So, we obtained the fresh mass of material $\left(M_{f}\right)$ and its respective dry mass $\left(M_{d}\right)$ (with a precision of $0.001 \mathrm{~g}$ ) after oven drying for $48 \mathrm{~h}$ at $70^{\circ} \mathrm{C}$. Leaf moisture (\%) was determined as

$L M=100 \times\left[\left(M_{f}-M_{d}\right) / M_{d}\right]$

Before testing flammability, we measured the thickness of ten leaves from each plant to estimate the surface to volume ratio $(\mathrm{S}: \mathrm{V})$ as

$$
S: V=S /(S * T)=1 / T
$$

where $S$ is surface, $V$ is volume and $T$ is thickness of the leaf. Thickness $(\mathrm{mm})$ was measured with a digital slide calliper in the central part of the leaf, avoiding the raquis.

Flammability was assessed by recording the time and the temperature of the following phases (cf. Trabaud 1976, Massari and Leopaldi 1995 and Alessio et al. 2008):

-Appearance of smoke, which corresponds to the moment when pyrolysis starts (smoke phase or phase I);

-Start of combustion, marked by the appearance of red spots and the occurrence of ignition (smoldering phase or phase II);

-Appearance of flame, when flame emission occurs (flaming phase or phase III).

Ten grams of fresh leaves from each plant were tested with a quartz epiradiator (Trabaud 1976; Massari and Leopaldi 1995) coupled with a digital thermometer equipped with a probe in contact with the sampled leaves. The leaves were placed on a wire mesh at a distance of $4 \mathrm{~cm}$ from the epiradiator source. The epiradiator releases heat and induces the first phase; afterward, the temperature progressively rises until flames appear. A digital timer was used to record the time at which the three phases appeared. We set the timer to start when the temperature reached $60^{\circ} \mathrm{C}$, to ensure that all the species received the same amount of heat. All the experiments were conducted 
in a closed environment to avoid any influence from draughts. The test ended when the whole sample had burned and the maximum temperature had been reached.

\section{Statistical analysis}

The variables derived from the fuel fractioning were: live fine fuel, dead fine fuel, live coarse fuel, dead coarse fuel, total live fuel, and total dead fuel. Live leaves were included in the live fine fraction. All these variables were considered relative to the total dry above-ground biomass of the individual (i.e., dry weight), resulting in a ratio for each variable. The total dry biomass and the dead fuel to live fuel ratio were also estimated. A two-factor ANOVA was conducted for each variable with the regenerative strategy (seeder, non-seeder) and site (Montgrí, Murta) as fixed factors. To better approximate normality, all variables were log-transformed. For comparisons between the two study sites, only species sampled on both study sites were considered.

We considered six variables to study flammability: temperature and time taken to reach each of the three phases. The differences in flammability between the species and the two regenerative strategies were tested by using GLMs (general linear models), including the two factors as fixed effects. LM and S:V were included as covariates (Papió 1994; Massari and Leopaldi 1995; Ralph 2001; Alessio 2006).

The differences between regenerative groups with reference to the temperatures at which the flammability phases arose were also analyzed by a repeated-measures ANOVA, where regenerative strategy and site were the between-subject factors and the flammability phase the within-subject factor (with three levels: smoke, smoldering, flaming). These analyses were repeated with the inclusion of the covariates (LM and S:V). Only species that burst into flame were included in these analyses.

The differences between regenerative groups and sites for the variables $L M$ and $S: V$ were also analyzed with two independent two-factor ANOVAs. To better approximate normality, LM was transformed to its $\log (x+1)$ and $S: V$ to its $\log (x)$. The relationships between LM and time to smoke and flaming, and between $S: V$ and time to smoke and smoldering, were fitted by a linear regression.

In these previous analyses (except for linear regressions) we worked with the species means (i.e. one value per species and site), which was obtained from the mean of the respective sampled individuals. One difficulty in species level analyses is the need to deal with the autocorrelation that may exist in parameters measured from species sharing a common ancestor (Blackburn and Duncan 2001; Garland et al. 2005; Sol et al. 2007). So, we also performed a GLMM (general linear mixed model) for all the fuel and combustion variables, considering a hierarchical nested design of species (as a random factor) between families to test whether there was any autocorrelation associated with the 'family' at the higher taxonomical level.

\section{RESULTS}

\section{Fuel loading}

Although the seeder species were smaller $(F=16.37, p<0.001$, Figure $1 a)$, they produce a type of fuel loading that make them more prone to burning (mean values per species are available in the Supplementary Material 1$)$. The dead-to-live-fuel ratio $(F=4.04, p=0.055$, Figure $1 \mathrm{~b})$, the live finefuel ratio $(F=6.83, p=0.015$, Figure $1 c)$ and the dead fine-fuel proportion were higher in seeders than in non-seeders $(F=5.99, p=0.021$, Figure $1 d)$. On the contrary, seeder species presented a lower proportion of live coarse fuel than non-seeders $(F=14.25, p=0.001$, Figure 1e, Figure 2 , Supplementary material 1$)$ but similar values in the dead coarse-fuel proportions $(F=0.056, p=$ $0.810)$. None of the statistical analyses showed a significant interaction between the regenerative strategy and site but no significant difference between the two study sites of Murta and Montgrí.

\section{Flammability}

Seeders presented lower smoldering and flaming temperatures and took longer time to smoke than non-seeders, although the differences for the latter were only marginally significant (Table 2, 
Figure 3). Repeated-Measures ANOVA analysis testing differences in temperatures over time endorsed these results, as the main difference between seeders and non-seeders was the former's tendency to reach the flaming phase at lower temperatures (Table 3, Figure 4). No significant differences were found between the study sites for any of the flammability variables (Table 2 and Table 3).

$\mathrm{S}: \mathrm{V}$ was not significantly different with respect to the regenerative strategies $(F=0.036, p=0.850)$ or the sites $(F=2.335, p=0.139)$; the interaction was also non-significant $(F=1.607, p=0.216)$.

Leaf moisture plays a significant role in determining temperature and time to smoke and flaming. $\mathrm{S}: \mathrm{V}$ significantly reduced the time and temperature before reaching the smoke phase (Table 2).

In Montgrí, leaf moisture was positively related to time to smoke and flaming (Fig. 5a and 5b), while $\mathrm{S}: \mathrm{V}$ was negatively related to time to smoke and smoldering (Fig. $5 \mathrm{c}$ and $5 \mathrm{~d}$ ). The same pattern was observed in Murtra, except that leaf moisture was positively related to the temperature to flaming instead of time to flaming.

No significant effect of the taxonomical affiliations was found in any of the studied variables, suggesting that taxonomical effects do not explain the variability found between regenerative strategies.

\section{DISCUSSION}

This study shows that woody species coexisting in a Mediterranean Basin shrubland that share a similar regenerative response after fire may also show similar structural features related to their ability to enhance wildfires. Although the studied seeder species, being smaller, tend to offer less fuel load than non-seeders, they show a higher proportion of fine dead material and less fuel moisture content than non-seeders, thereby fomenting the spread of fire and increasing the danger of fire. The studied seeders are also species with rapid combustion, as suggested by the lower smoldering and flaming temperatures of the leaves, while non-seeders have more coarse fuel, promoting longer but slower fires (Andrews and Bevins 2003). This pattern concurs with previous studies which suggest that species combustibility could be highly influenced by plants' fuel structure (Schwilk 2003). The absence of differences between the two sites in this respect confirms that the observed patterns are mostly attributable to the intrinsic properties of species and not to local conditions.

These features of the studied seeders are probably due to structural and physiological traits related to the following facts. First, seeders present a particular life history (which is characterized by a short lifespan), small size of above-ground organs, shallow roots and relatively high seedling establishment, while non-seeders would show the opposite (high biomass and a long lifespan with high survival after fire, thanks to their resprouting capacity) (Terradas 2001). Secondly, their ability to tolerate drought conditions typical of Mediterranean environments, resulting in, among other physiological features, high leaf water seasonal variation, low relative water content and low leaf dry-matter content (Saura-Mas and Lloret 2007; Saura-Mas et al. 2009).

Most seeder lineages diversified in the Mediterranean Basin during the Quaternary, contemporary with the Mediterranean climate (Herrera 1992; Verdú et al. 2003; Pausas and Verdú 2005). Therefore, their ability to germinate abundantly after disturbances may be due both to fire and to a highly fluctuating climate with harsh dry periods. Both types of environmental variability probably became more prevalent during the early Quaternary (Jalut et al. 2000; Scott 2000; Scott 2002). In recent years, there has been intense debate about the evolution of flammability. Some authors maintain that species most suited to fire-prone habitats (i.e. those that take advantage of wildfires to recruit) may have evolved flammability to compete successfully with other species less well adapted to fire (Mutch 1970; Zedler 1995; Bond and Keeley 2005; Bond et al. 2005). Our study supports the hypothesis that seeders exhibit more flammable characteristics than non-seeders. 
However, fire may not be the only trigger for diversification in species from fire-prone Mediterranean ecosystems (Lavorel and Garnier 2002). Flammability differences between seeders and non-seeders cannot be directly attributed to differences in leaf moisture, since we obtained the same result regardless of whether or not LM was included as a covariate in the model. In fact, we did not find any differences in LM between these groups. Differences in the mineral content and/or volatile compounds, both of which contribute to high flammability and are very abundant in plants in the Mediterranean Basin (Owens et al. 1998; Alessio et al. 2004; Alessio 2006, Greenberg et al. 2006), may help explain differences in flammability between seeders and non-seeders. Certain flammability-related chemical and structural properties of plants could also be the result of physiological and morphological responses to other environmental constraints typical of Mediterranean ecosystems, with their seasonal high temperatures, low water storage and high radiation (Arnan et al. 2007; Lloret et al. 2007). In fact, in many communities of the western Mediterranean Basin seedling recruitment of these species is not exclusively fire-dependent (Lloret 1998; Lloret et al. 2005b). Flammable properties may therefore enhance seeder populations after fire and these features would also help them tolerate drought periods.

Our study suggests that seeders need less energy to burst into flame, thus increasing the fire hazard. Although we did not measure the heat released by the combustion of seeders, other studies (Heim 1974; Elvira 1989) suggest that these species may have lower specific heat power, promoting low to moderate temperatures. This is corroborated by the lower fuel load reported in our study. Seeders from these communities have a higher content of minerals such as calcium and phosphorous (Saura-Mas and Lloret 2009), which would result in a lower intensity of fire endothermal reactions (Philpot 1970). This moderate fire intensity would enhance seed germination but would avoid the high temperatures that deplete seed viability (Fenner 1992; Salvador and Lloret 1995; De Luis et al. 2005; Paula and Pausas 2008). As a result, this strategy could promote a positive feedback that allows maintaining seeder populations, as has been suggested in Mediterranean ecosystems dominated by the grass Ampelodesmos mauritanica (Grigulis et al. 2005). However, we did not undertake any direct measurements of the specific heat power of different species, although this would be necessary for a more comprehensive analysis of the feedbacks between vegetation and fire, which, in turn, would be determined by the relationship between post-fire regenerative strategies and fire-promoting attributes.

In general, low water content in leaves was a determining factor in the achievement of pyrolisis (smoking phase) and facilitated flame production (flaming phase). High S:V also contributed to the attainment of pyrolisis and ignition. Leaves with higher $S: V$ reach the temperature and time needed to achieve each subsequent flammability phase earlier and at lower temperature since they have a relatively greater surface exposed to heat, and oxygen. This pattern seems to indicate that ignition (the smoldering phase) depends greatly on intrinsic plant properties such as leaf morphology, while leaf water content, a variable more dependent on environmental conditions, has a greater effect on flame production.

Information about the flammability and fuel characteristics of the species dominating plant communities may be of great importance to the management of fire prevention and extinction, particularly in regions such as the western Mediterranean Basin, where the frequency, extent and intensity of wildfires have increased in recent decades (Moreno and Oechel 1995; Piñol et al. 1998; Pausas 2004). Our study reveals that the studied seeders are more flammable than non-seeders, as they need lower temperatures to produce flame and display rapid combustion (not to mention their high percentage of fine and dead fuel). As a result, ecosystems dominated by seeder species will be more prone to fire than those dominated by non-seeder species. Seeder species also present a lower fuel load, which is likely to result in less intense fires that can be fought more easily. In contrast, non-seeders need higher temperatures to start combustion and their high amounts of fuel load may produce wildfires that are not easily extinguishable. If we consider that fire regime influences vegetation dynamics and composition, in accordance with plants' fireregenerative traits (Zedler et al. 1983; Lloret et al. 2003; Bond et al. 2005), our study affirms the existence of a link between the post-fire regenerative traits and flammability traits on the studied 
shrubland. We thus provide empirical elements to support the notion of a positive feedback in which the risk of fire is probably influenced, in its turn, by a community's component species.

\section{ACKNOWLEDGEMENTS}

We would like to thank M. Jané, E. Martí, A. Vila, J. Garcia, B. Moreira, S. Ribeiro and C. Beseler for helping in the field and in the lab work. Also, special thanks are due to J. Piñol for his advice and suggestions, and to J. Peñuelas and G. Alessio for supporting the flammability tests. This study was funded by the Department of Universities, Research and Information Society of the Generalitat de Catalunya, the European social funds, and the Spanish MCYT projects REN 200307198 and CGL2006-01293/BOS. It also contributes to the European research group (GDRE) "Mediterranean and mountain ecosystems in a changing world" funded by the Generalitat de Catalunya and CNRS. CEAM is supported by the Generalitat Valenciana and Bancaixa.

\section{LITERATURE CITED}

Alberdi L, Cavero R (2003) Flora vascular post-incendio en un carrascal de Nazar (Navarra). Publicaciones de Biología, Universidad de Navarra, Serie Botánica 15, 1-17.

Alessio GA, Peñuelas J, Llusià J, Ogaya R, Estiarte M (2008) Influence of water and terpenes on flammability in some dominant Mediterranean species. International Journal of Wildland Fire 17 (2), 274-286.

Alessio GA (2006) Plant water and volatile organic compounds in flammability risk of Mediterranean woody species. Ph.D. Thesis, Universita del Molise, Roma

Alessio GA, De Lillis M, Fanelli M, Pinelli P, Loreto F (2004) Direct and indirect impacts of fire on isoprenoid emissions from Mediterranean vegetation. Functional Ecology 18, 357-364.

Andrews PL, Bevins CD (2003) BehavePlus fire modeling system, version 2.0: overview. In 'Proceedings of the Second International Wildland Fire Ecology and Fire Management Congress and Fifth Symposium on Fire and Forest Meteorology'. pp. 5-11. (Orlando, FL)

Arnan X, Rodrigo A, Retana J (2007) Post-fire regeneration of Mediterranean plant communities at a regional scale is dependent on vegetation type and dryness. Journal of Vegetation Science 18, 111-122.

Bellingham P, Sparrow A (2000) Resprouting as a life history strategy in woody plant communities. Oikos 89, 409-416.

Blackburn TM, Duncan RP (2001) Determinants of establishment success in introduced birds. Nature 414, 195-197.

Bolòs O, Vigo J, Masalles RM, Ninot JM (Eds) (2005) Flora manual dels Països Catalans. (Pòrtic: Barcelona)

Bond WJ, Keeley JE (2005) Fire as a global 'herbivore': the ecology and evolution of flammable ecosystems. Trends in Ecology and Evolution 20 (7), 387-394.

Bond WJ, Midgley JJ (1995) Kill the neighbour: an individualistic argument for the evolution of flammability. Oikos 73, 79-85.

Bond WJ, Midgley JJ (2003) The evolutionary ecology of sprouting in woody plants. International Journal of Plant Science 164 (3), 103-114.

Bond WJ, Van Wilgen BW (Eds) (1996) 'Fire and plants'. (Chapman \& Hall: London)

Bond WJ, Woodward FI, Midgley GF (2005) The global distribution of ecosystems in a world without fire. New Phytologist 165, 525-538.

Cornelissen JHC, Lavorel S, Garnier E, Díaz S, Buchmann N, Gurvich DE, Reich PB, Steege H, Morgan HD, Heijden MGA, Pausas JG, Poorter H (2003) A handbook of protocols for standardised and easy measurement of plant functional traits worldwide. Australian Journal of Botany 51, 335-380. 
Cucó M (1987) Mecanismes de regeneració. In 'Ecosistemes terrestres: la resposta als incendis i a d'altres pertorbacions'. (Ed J Terradas) pp. 45-62. (Diputació de Barcelona: Barcelona)

De Luis M, Baeza MJ, Raventós J, González-Hidalgo JC (2004) Fuel characteristics and fire behaviour in mature Mediterranean gorse shrublands. International Journal of Wildland Fire 13, 79-87.

De Luis M, Raventós J, González-Hidalgo JC. (2005) Factors controlling seedling germination after fire in Mediterranean gorse shrublands. Implications for fire prescription. Journal of Environmental Management 76, 159-166.

Dimitrakopoulos A, P., Panov P, I. (2001) Pyric properties of some dominant Mediterranean vegetation species. International Journal of Wildland Fire 10, 23-27.

Elvira LM, Hernando C (Eds) (1989) Inflamabilidad y energía de las especies de sotobosque. (Ministerio de Agricultura, Pesca y Alimentación. Instituto Nacional de Investigaciones Agrarias: Madrid)

Eugenio M, Lloret F (2004) Fire recurrence effects on the structure and composition of Mediterranean Pinus halepensis communities in Catalonia (northeast Iberian Peninsula). Écoscience 11, 446-454.

Fenner M (Ed) (1992) 'Seeds. The ecology of regeneration in plant communities.' (CAB international: Oxon, United Kingdom)

Franklin J, Syphard AD, Mladenoff DJ, He HS, Simons DK, Martin RP, Deutschman DD, O'Leary JF (2001) Simulating the effects of different fire regimes on plant functional groups in southern California. Ecological Modelling 142, 261-283.

Garland TJ, Bennett AF, Rezende EL (2005) Phylogenetic approaches in comparative physiology. The Journal of Experimental Biology 208, 3015-3035.

Greenberg JP, Friedli H, Guenther AB, Hanson D, Harley P, Karl T (2006) Volatile organic emissions from the distillation and pyrolysis of vegetation. Atmospheric Chemistry and Physics 6, 81-91.

Grigulis K, Lavorel S, Davies ID, Dossantos A, Lloret F, Vilà M (2005) Landscape-scale positive feedbacks between fire and expansion of the large tussock grass, Ampelodesmos mauritanica in Catalan shrublands. Global Change Biology 11, 1042-1053.

Heim G (1974) L'utilité du concept de valeur énergétique en écologie: une étude basée sur des mesures effectuées sur des plantes méditerranéennes. Oecologia Plantarum 9 (3), 281-286.

Herrera C (1992) Historical effects and sorting processes as explanations for contemporary ecological patterns: character syndromes in Mediterranean woody plants. American Naturalist 140, 421-446.

Jalut G, Esteban-Amat A, Bonnet L, Gauquelin T, Fontugne M (2000) Holocene climatic changes in the Western Mediterranean from south-east France to south-east Spain. Palaeogeography, Palaeoclimatology, Palaeoecology 160, 255-290.

Knox KJE, Clarke PJ (2005) Nutrient availability induces contrasting allocation and starch formation in resprouting and obligate seeding shrubs. Functional Ecology 19, 690-698.

Lavorel S, Garnier E (2002) Predicting changes in community composition and ecosystem functioning from plant traits: revisiting the Holy Grail. Functional Ecology 16, 545-556.

Lloret F (1998) Fire, canopy cover and seedling dynamics in Mediterranean shrubland of northeastern Spain. Journal of Vegetation Science 9 (3), 417-430

Lloret F, Estevan H, Vayreda J, Terradas J (2005a) Fire regenerative syndromes of forest woody species across fire and climatic gradients. Oecologia 146 (3), 461-468.

Lloret F, Lobo A, Estevan H, Maisongrande P, Vayreda J, Terradas J (2007) Woody plant richness and NDVI response to drought events in Catalonian (northeastern Spain) forests. Ecology 88 (9), 2270-2279. 
Lloret F, Pausas J, Vilà M (2003) Responses of Mediterranean plant species to different fire frequencies in Garraf Natural Park (Catalonia, Spain): field observations and modelling predictions. Plant Ecology 167, 223235.

Lloret F, Peñuelas J, Estiarte M (2005b) Effects of vegetation canopy and climate on seedling establishment in Mediterranean shrubland. Journal of Vegetation Science 16 (1), 67-76.

Lloret F, Vilà M (1997) Clearing of vegetation in Mediterranean garrigue: response after a wildfire. Forest Ecology and Management 93, 227-234.

Lloret F, Vilà M (2003) Diversity patterns of plant functional types in relation to fire regime and previous land use in Mediterranean woodlands. Journal of Vegetation Science 14, 387-398.

Lloret F, Verdú M, Flores-Hernández N, Valiente-Banuet A (1999) Fire and resprouting in Mediterranean ecosystems: insights from an external biogeographical region, the mexical shrubland. American Journal of Botany 86, 1655-1661.

Massari G, Leopaldi A (1995) Leaf flammability in Mediterranean species. Plant Biosystems 132 (1), 29-38.

Moreno JM, Oechel WC (Eds) (1995) 'Global change and Mediterranean-type ecosystems.' (SpringerVerlag: New York)

Mutch RW (1970) Wildland fires and ecosystems - a hypothesis. Ecology 51 (6), 1046-1051.

Ninyerola M, Pons X, Roure J (2000) A methodological approach of climatological modelling of air temperature and precipitation through GIS techniques. International Journal of Climatology 20, 1823-1841.

Ninyerola M, Pons X, Roure J, Martín VJ, Raso J, Clavero P (2003) Atles Climàtic Digital de Catalunya. CDROM. (Servei Meteorològic de Catalunya and Departament de Medi Ambient de la Generalitat Catalunya)

Owens MK, Lin CD, Taylor CA, Whisenant SG (1998) Seasonal patterns of plant flammability and monoterpenoid content in Juniperus ashei. Journal of Chemical Ecology 24 (12), 2115-2129.

Papió CP (1988) Respuesta al fuego de las principales especies de la vegetación de Garraf (Barcelona). Orsis 3, 87-103.

Papió CP (Ed) (1994) 'Ecologia del foc i regeneració en garrigues i pinedes mediterrànies.' (Institut d'Estudis Catalans: Hospitalet de Llobregat)

Papió CP, Trabaud L (1991) Comparative study of the aerial structure of five shrubs of Mediterranean shrublands. Forest Science 37 (1), 146-159.

Pate JS, Froend RH, Bowen BJ, Hansen A, Kuo J (1990) Seedling growth and storage characteristics of seeder and resprouter species species of Mediterranean-type ecosystems of SW Australia. Annals of Botany 65, 585-601.

Paula S, Pausas JG (2008) Burning seeds: germinative response to heat treatments in relation to respouting ability. Journal of Ecology 96, 543-552.

Paula S, Arianoutsou M, Kazanis D, Tavsanoglu Ç, Lloret F, Buhk C, Ojeda F, Luna B, Moreno JM, Rodrigo A, Espelta JM, Palacio S, Fernández-Santos B, Fernandes PM, and Pausas JG (2009) Fire-related traits for plant species of the Mediterranean Basin. Ecology 90: 1420.

Pausas J, Bradstock R, Keith D, Keeley J, GCTE network (2004) Plant functional traits in relation to fire in crown-fire ecosystems. Ecology 85, 1085-1100.

Pausas J, G. (2004) Changes in fire and climate in the Eastern Iberian Peninsula (Mediterranean Basin). Climatic Change 63, 337-350. 
Pausas J, G., Bradstock R, A. (2007) Fire persistence traits of plants along a productivity and disturbance gradient in mediterranean shrublands of south-east Australia. Global Ecology and Biogeography 16 (3), 330340.

Pausas J, G., Lloret F (2007) Spatial and temporal patterns of plant functional types under simulated fire regimes International Journal of Wildland Fire 16 (4), 484-492.

Pausas J, Verdú M (2005) Plant persistence traits in fire-prone ecosystems of the Mediterranean Basin: a phylogenetic approach. Oikos 109, 196-202.

Pérez AJ (1994) 'Atlas climático de la Comunidad Valenciana'. (Generalitat Valenciana - Conselleria d'Obres Públiques, Urbanisme i Transports: València).

Philpot CW (1970) Influence of mineral content on the pyrolysis of plant materials. Forest Science 16, 461471.

Piñol J, Terradas J, Lloret F (1998) Climate warming wildfire hazard, and wildfire occurrence in coastal eastern Spain. Climatic Change 38, 345-357.

Pons X, Vayreda J (1996) La predicció del risc: poder calorífic, inflamabilitat i combustibilitat. In 'Ecologia del foc.' (Ed. J Terradas) pp. 82-95. (Proa: Barcelona)

Ralph M, Nelson, Jr. (2001) Water relations of forest fuels. In 'Forest fires. Behavior and ecological effects.' (Eds E Johnson and K Miyanishi) pp. 79-150 (Academic press: San Diego, California)

Raunkiaer C (1934) The life form of plants and statistical plant geography. (Oxford University Press: Oxford, UK)

Rodrigo A, Retana J, Picó FX (2004) Direct regeneration is not the only response of Mediterranean forests to large fires. Ecology 85, 716-729

Salvador R, Lloret F (1995) Germinación en el laboratorio de varias especies arbustivas mediterráneas: efecto de la temperatura. Orsis 10, 25-34.

Saura-Mas S, Lloret F (2007) Leaf and shoot water content and leaf dry matter content of Mediterranean woody species with different post-fire regenerative strategies. Annals of Botany 99 (3), 545-554.

Saura-Mas S, Lloret F (2009) Linking post-fire regenerative strategy and leaf nutrient content in Mediterranean woody plants. Perspectives in Plant Ecology, Evolution and Systematics 11, 219-229.

Saura-Mas S, Shipley B, Lloret F (2009) Relationship between post-fire regeneration and leaf economics spectrum in Mediterranean woody species. Functional ecology 23, 103-110.

Scarff FR, Westoby M (2006) Leaf litter flammability in some semi-arid Australian woodlands. Functional Ecology 20, 745-752.

Scott AC (2000) The Pre-quaternary history of fire. Palaeogeography, Plaeoclimatology, Palaeoecology 164, 281-329.

Scott L (2002) Microscopic charcoal in sediments: Quaternary fire history of the grassland and savanna regions in South Africa. Journal of Quaternary Science 17 (1), 77-86.

Schwilk DW (2003) Flammability is a niche construction trait: canopy architecture affects fire intensity. The American Naturalist 162 (6), 725-733.

Schwilk DW, Ackerly DD (2001) Flammability and serotiny as strategies: correlated evolution in pines. Oikos 94, 326-336.

Schwilk DW, Ackerly DD (2005) Is there a cost to resprouting? Seedling growth rate and drought tolerance in sprouting and nonsprouting in Ceanothus (Rhamnaceae). American Journal of Botany 92, 404-410. 
Sol D, Székely T, Liker A, Lefebvre L (2007) Big-brained birds survive better in nature. Proceedings of the Royal Society of Biological Sciences 274, 763-769.

Trabaud L (1976) Inflammabilité et combustibilité des principales espèces des garrigues de la région méditerranéenne. Oecologia Plantarum 11, 117-136.

Terradas J (2001) 'Ecología de la vegetación. De la ecofisiología de las plantas a la dinámica de comunidades y paisajes.' (Omega: Barcelona)

Trabaud L (1989) 'Les feux de forêts. Mecanismes, comportement et environnement.' (France-selection: Aubervilliers. France)

Troumbis AY, Trabaud L (1989) Some questions about flammability in fire ecology. Acta Oecologica Oecologia Plantarum 10 (2), 167-175.

Valette J-C, Sol B, Moro C (1994) Flammability parameters and soil water reserve to improve the forecast of the meteorological forest fire danger index. In 'Proceedings of the 2nd international conference of forest fire research'. pp. 611-624. (Coimbra)

Verdaguer D, Ojeda F (2002) Root starch storage and allocation patterns in seeder and resprouter seedlings of two Cape Erica (Ericaceae) species. American Journal of Botany 89, 1189-1196.

Verdú M (2000) Ecological and evolutionary differences between Mediterranean seeders and resprouters. Journal of Vegetation Science 11, 265-268.

Verdú M, Dávila P, García-Fayos P, Flores-Hernández N, Valiente-Vanuet A (2003) 'Convergent' traits of mediterranean woody plants belong to pre-mediterranean lineages. Biological Journal of the Linnean Society 78, 415-427.

Viegas DX, Piñol J, Viegas MT, Ogaya R (2001) Estimating live fine fuels moisture content using meteorologically-based indices. International Journal of Wildland Fire 10, 223-240.

Vila A, Saura-Mas S, Lloret F (2008) Fire frequency effects on species composition of a Mediterranean shrubland. Écoscience 15 (4), 519-528.

Vilà M, Lloret F (2000) Woody species tolerance to the expanding perennial tussock-grass Ampelodesmos mauritanica after fire. Journal of Vegetation Science 11, 597-606.

Vilà M, Lloret F, Ogheri F, Terradas J (2001) Positive fire grass feedback in Mediterranean Basin woodlands. Forest Ecology and Management 147, 3-14.

Whelan RJ (Ed) (1995) 'The ecology of fire'. (Cambridge University Press: Cambridge, Great Britain)

Zedler PH, Gautier CR, McMaster GS (1983) Vegetation change in response to extreme events: the effect of a short interval between fires in California chaparral and coastal scrub. Ecology 64 (4), 809-818.

Zedler PH (1995) Are some plants born to burn? Trends in Ecology and Evolution 10 (10), 393-395. 


\section{TABLES}

Table 1. Study species (Bolòs et al. 2005), families, post-fire regenerative strategies (seeder $=\mathrm{S}$, non-seeder $=\mathrm{NS})$ and life-form according to Raunkiaer $(1936 ; \mathrm{MP}=$ macro-phanerophyte, $\mathrm{P}=$ phanerophyte, NP = nano-phanerophyte, $\mathrm{PV}=$ phanerophyte-vine, $\mathrm{C}=$ chamephyte). $\mathrm{F}$ and $\mathrm{FL}$ columns indicate whether the species was used in the experiment to determine flammability $(F)$ and fuel loading (FL). Numbers indicate the sites where the species were sampled $(1=$ Montgri, 2 $=$ Murta).

\begin{tabular}{|c|c|c|c|c|c|}
\hline Study Species & Family & Life-form & $\mathbf{F}$ & FL & $\begin{array}{c}\text { Regenerative } \\
\text { strategy }\end{array}$ \\
\hline Calicotome spinosa (L.) LK & Fabaceae & $\mathrm{NP}$ & & $1-2$ & $\mathrm{~S}$ \\
\hline Cistus albidus L. & Cistaceae & NP & $1-2$ & $1-2$ & S \\
\hline Cistus crispus L. & Cistaceae & NP & $1-2$ & & S \\
\hline Cistus monspeliensis L. & Cistaceae & NP & $1-2$ & $1-2$ & S \\
\hline Cistus salviifolius L. & Cistaceae & NP & $1-2$ & & $\mathrm{~S}$ \\
\hline Coronilla minima L. & Fabaceae & C & $1-2$ & $1-2$ & NS \\
\hline Daphne gnidium L. & Thymelaeaceae & NP & $1-2$ & $1-2$ & NS \\
\hline Dorycnium hirsutum (L.) Ser. in DC. & Fabaceae & C & & 1 & $\mathrm{~s}$ \\
\hline Dorycnium pentaphyllum Scop. & Fabaceae & C & & 1 & $S$ \\
\hline Fumana ericoides (Caav.) Gandg. & Cistaceae & C & & $1-2$ & S \\
\hline Fumana laevipes (L.) Spach. & Cistaceae & C & & 1 & S \\
\hline Fumana thymifolia L. & Cistaceae & C & & $1-2$ & $\mathrm{~s}$ \\
\hline Globularia alypum L. & Globulariaceae & NP & $1-2$ & $1-2$ & $S$ \\
\hline Helichrysum stoechas (L.) Moench. & Asteraceae & C & $1-2$ & 1 & s \\
\hline Lavandula latifolia Med. & Lamiaceae & C & $1-2$ & & $\mathrm{~s}$ \\
\hline Lonicera implexa Aiton & Caprifoliaceae & PV & 1 & & NS \\
\hline Olea europaea L. & Oleaceae & MP & 1 & & NS \\
\hline Osyris alba L. & Santalaceae & NP & & $1-2$ & NS \\
\hline Phillyrea angustifolia L. & Oleaceae & NP & $1-2$ & $1-2$ & NS \\
\hline Pistacia lentiscus L. & Anacardiaceae & MP & $1-2$ & $1-2$ & NS \\
\hline Quercus coccifera L. & Fagaceae & NP & $1-2$ & 1 & NS \\
\hline Quercus ilex L. & Fagaceae & MP & 1 & & NS \\
\hline Rhamnus alaternus L. & Rhamnaceae & $\mathrm{P}$ & $1-2$ & $1-2$ & NS \\
\hline Rhamnus lycioides L. & Rhamnaceae & $\mathrm{P}$ & & 2 & NS \\
\hline Rosmarinus officinalis L. & Lamiaceae & NP & $1-2$ & $1-2$ & $S$ \\
\hline Smilax aspera L. & Liliaceae & PV & 1 & & NS \\
\hline Staehelina dubia L. & Asteraceae & C & 1 & & $\mathrm{~s}$ \\
\hline Teucrium polium L. & Lamiaceae & C & $1-2$ & $1-2$ & $\mathrm{~s}$ \\
\hline Thymus vulgaris $\mathrm{L}$. & Lamiaceae & C & & $1-2$ & $\mathrm{~s}$ \\
\hline
\end{tabular}


Table 2. Summary of results for GLM accounting for the variation in temperature and time needed to reach the phases of smoke, smoldering and flaming. Two fixed effects (regenerative strategy and site) and two covariates (leaf moisture, LM and surface to volume ratio of the leaf, $S: V$ ) were considered in these analyses.

\begin{tabular}{|c|c|c|c|c|c|c|c|c|c|c|c|c|}
\hline & \multicolumn{6}{|c|}{ Temperature } & \multicolumn{6}{|c|}{ Time } \\
\hline & \multicolumn{2}{|c|}{ Smoke } & \multicolumn{2}{|c|}{ Smoldering } & \multicolumn{2}{|c|}{ Flaming } & \multicolumn{2}{|c|}{ Smoke } & \multicolumn{2}{|c|}{ Smoldering } & \multicolumn{2}{|c|}{ Flaming } \\
\hline & $\mathbf{F}$ & $\mathbf{p}$ & $\mathbf{F}$ & $\mathbf{p}$ & $\mathbf{F}$ & $\mathbf{p}$ & $\mathbf{F}$ & $\mathbf{p}$ & $\mathbf{F}$ & $\mathbf{p}$ & $\mathbf{F}$ & $p$ \\
\hline LM & 5.210 & 0.032 & 1.576 & 0.221 & 5.436 & 0.029 & 14.428 & 0.001 & 0.382 & 0.542 & 7.427 & 0.013 \\
\hline S:V & 7.071 & 0.014 & 1.485 & 0.235 & 0.239 & 0.630 & 13.773 & 0.001 & 3.994 & 0.057 & 0.427 & 0.521 \\
\hline Regenerative strategy & 1.421 & 0.245 & 9.686 & 0.005 & 5.114 & 0.034 & 3.961 & 0.058 & 2.241 & 0.147 & 0.628 & 0.438 \\
\hline Site & 4.200 & 0.052 & 1.222 & 0.280 & 0.673 & 0.421 & 1.148 & 0.295 & 0.078 & 0.783 & 1.102 & 0.307 \\
\hline Reg. strategy $x$ Site & 0.767 & 0.390 & 0.316 & 0.579 & 0.971 & 0.335 & 0.038 & 0.847 & 0.005 & 0.946 & 0.323 & 0.576 \\
\hline
\end{tabular}

Table 3. Summary of results of the Repeated-Measures ANOVAs considering temperature as the dependent variable and flammability phase (FP) (smoke, smoldering and flaming) as the withinsubject factor. Two between-subject factors (regenerative strategy and site) and two covariates (leaf moisture, LM and surface to volume ratio of the leaf, $\mathrm{S}: \mathrm{V}$ ) were considered in the model.

\begin{tabular}{lcccc} 
& \multicolumn{2}{c}{ Without S:V and LM } & \multicolumn{2}{c}{ With S:V and LM } \\
\cline { 2 - 5 } & $\mathbf{F}$ & $\mathbf{p}$ & $\mathbf{F}$ & $\mathbf{p}$ \\
\hline Regenerative strategy & 4.898 & 0.037 & 6.903 & 0.015 \\
Site & 0.367 & 0.550 & 0.045 & 0.833 \\
Reg. Strategy x Site & 0.312 & 0.582 & 0.890 & 0.356 \\
FP & 93.854 & 0.000 & 5.035 & 0.011 \\
FP x Reg. Strategy & 2.880 & 0.066 & 4.303 & 0.020 \\
FP x Site & 0.099 & 0.906 & 1.346 & 0.271 \\
FP x Reg. Strategy x Site & 0.057 & 0.945 & 0.895 & 0.416 \\
\hline
\end{tabular}




\section{FIGURES}

Figure 1. Means and standard errors of total plant biomass (a), dead fuel-live fuel ratio (b), live fine fuel ratio (c), dead fine fuel ratio (d) and live coarse fuel ratio (e) for the regenerative strategies (seeders and non-seeders) and for the two study sites (Murta and Montgrí). Montgrí values are represented by circles (०) and Murta by triangles ( $\Delta)$. In all cases, differences between regenerative strategies are significant $(p<0.05)$ (Fig. 1b presents a marginally significant difference), and those between the sites for a given strategy are not.

(a)

(b)
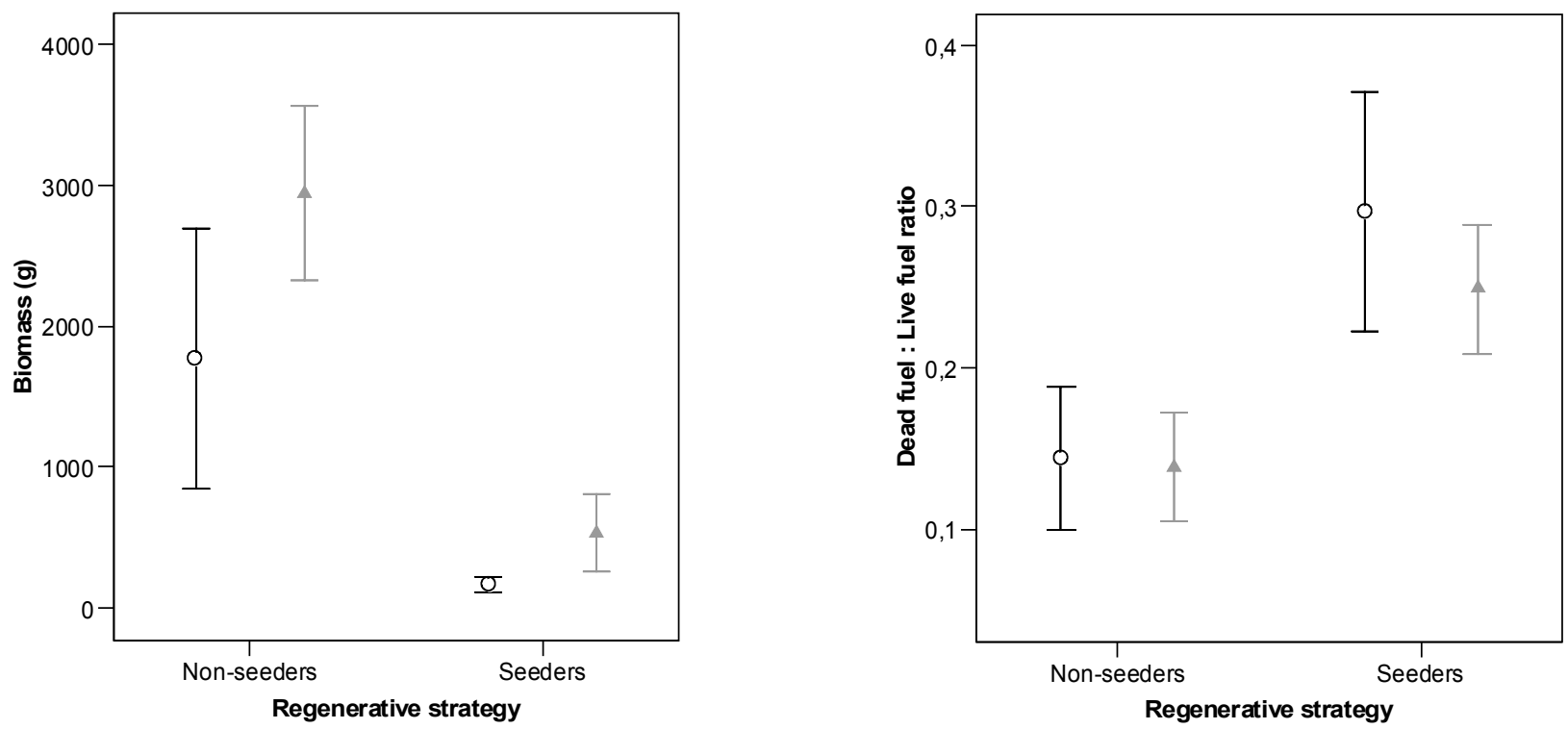
(c)

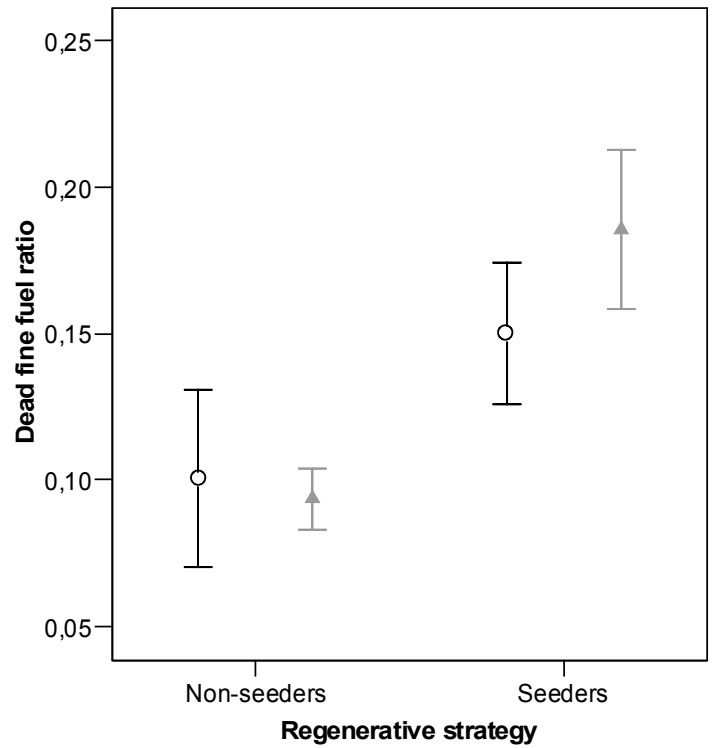

(e)

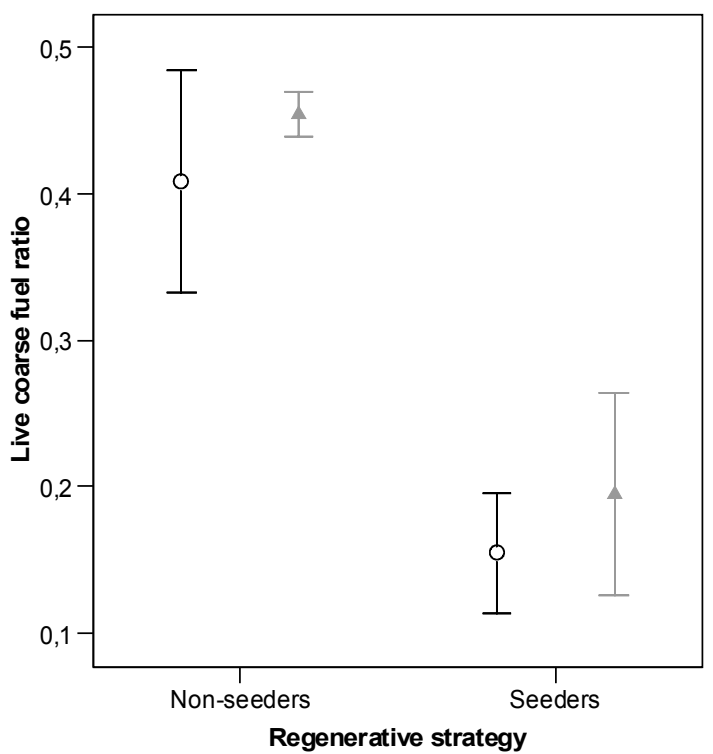

(d)

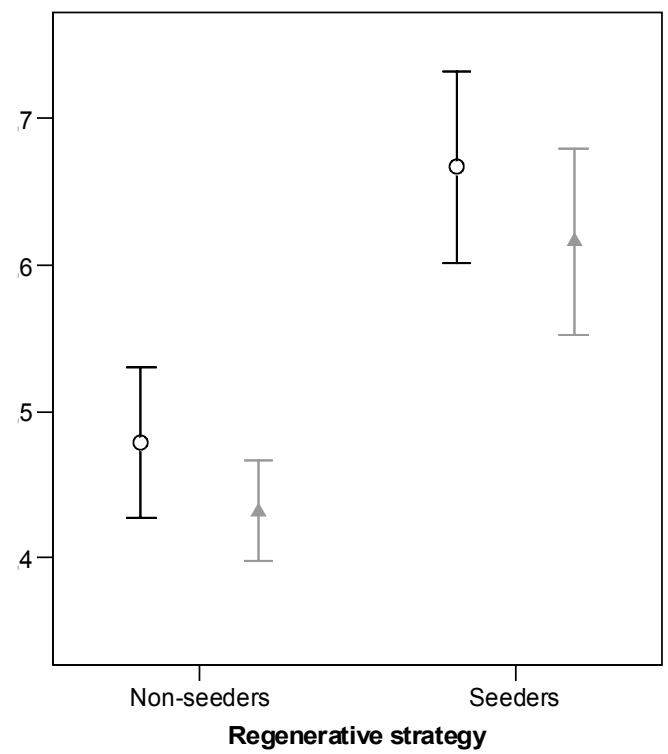

Regenerative strategy 
Figure 2. Proportion of each fraction (leaves, dead, live, fine and coarse material) in relation to the total dry weight for each species in the two study sites (Montgrí and Murta). Species are first sorted according to the regenerative type and then in alphabetical order. Horizontally, the values for each species on each site (Murta and Montgri) are represented. Species codes are: $\mathrm{CSPI}=$ Calicotome spinosa, $\mathrm{CMON}=$ Cistus monspeliensis, $\mathrm{CA}=$ Cistus albidus, $\mathrm{FE}=$ Fumana ericoides, $\mathrm{FT}=$ Fumana thymifolia, $\mathrm{GA}=$ Globularia alypum, $\mathrm{RO}=$ Rosmarinus officinalis, $\mathrm{TP}=$ Teucrium poleum, $\mathrm{TV}=$ Thymus vulgaris, $\mathrm{CMIN}=$ Coronilla minima, $\mathrm{DG}=$ Daphne gnidium, $\mathrm{OA}$ = Osyris alba, $\mathrm{PA}=$ Phyllirea angustifolia, $\mathrm{PL}=$ Pistacia lentiscus, $\mathrm{RA}=$ Rhamnus alaternus.

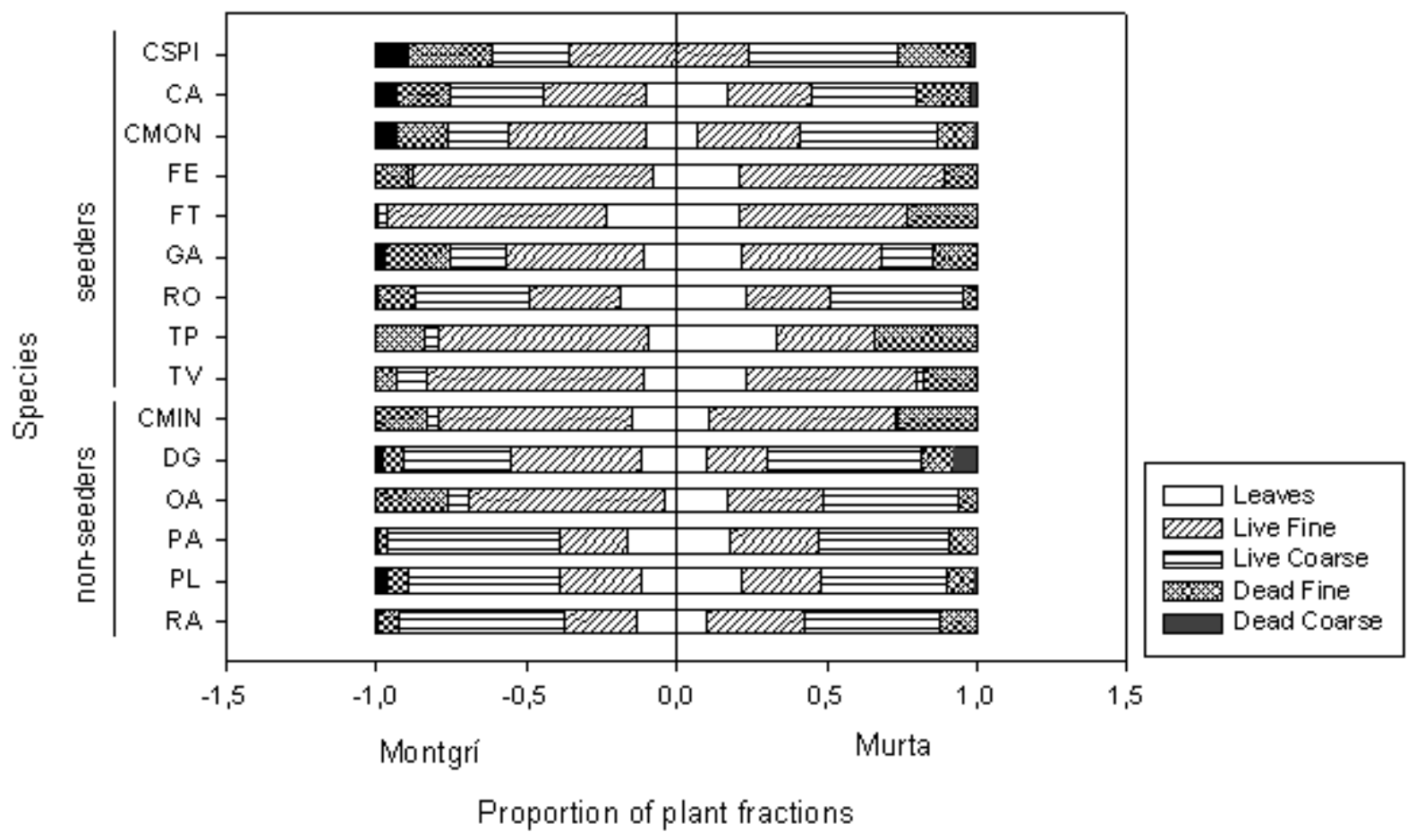


Figure 3. Mean and standard errors of temperature and time needed to achieve the flammability phases: smoke, smoldering and flaming. The values are drawn for each regenerative strategy (seeders and non-seeders) and site (Montgrí and Murta). The mean and standard error for each regenerative strategy is drawn with a black circle after pooling the data from both sites for each species. For statistical analysis, see Table 3.
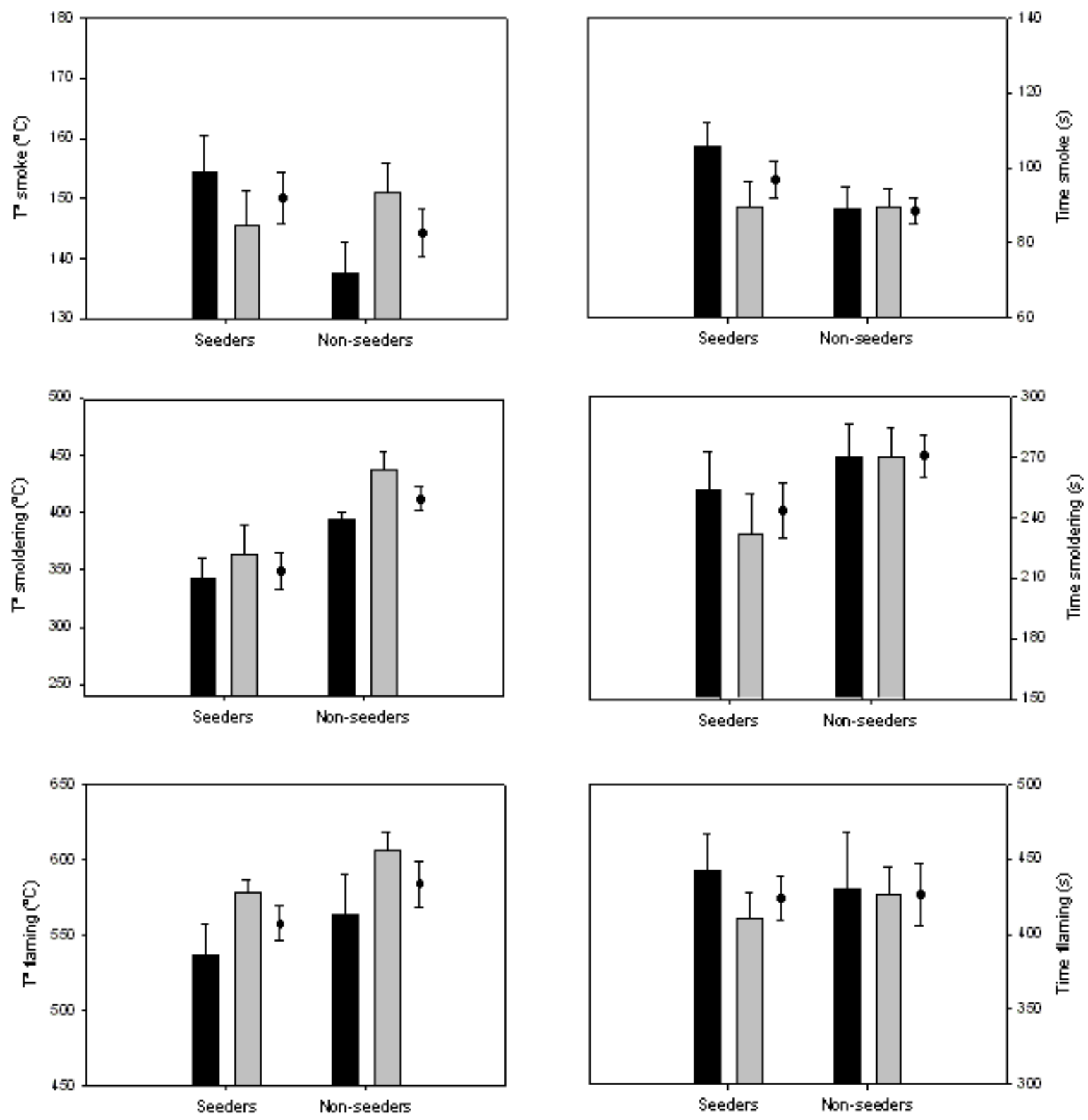
Figure 4. Mean and standard error of temperature needed to achieve each flammability phase for the two regenerative strategies. Lower-case letters indicate differences between flammability phases for each regenerative strategy and uppercase letters indicate differences between regenerative strategies for each phase (post-hoc Fisher LSD, after repeated-measures ANOVA including leaf moisture and leaf surface:volume as covariates). Data from the two sites have been pooled.

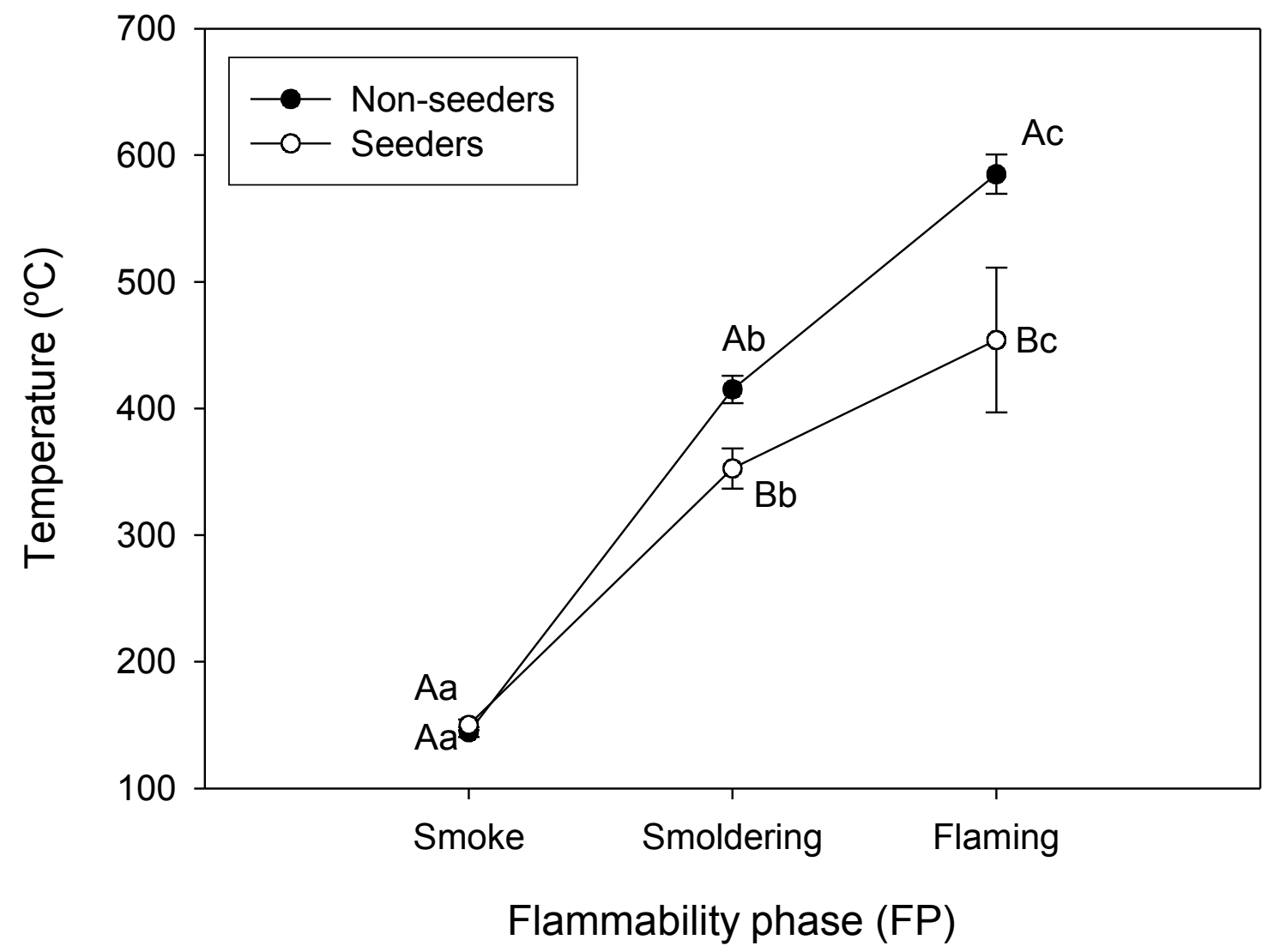


Figure 5. Relationship between time to achieve smoke phase (a) and flaming phase (b) and leaf moisture; and relationship between time to achieve smoke phase (c) and smoldering phase (d) and S:V ratio, following a linear regression for species from Montgrí site. S:V ratio was transformed to its $\operatorname{Ln}(\mathrm{x})$ to better approximate normality. Similar results were found for species from Murta (data not shown).

(a)

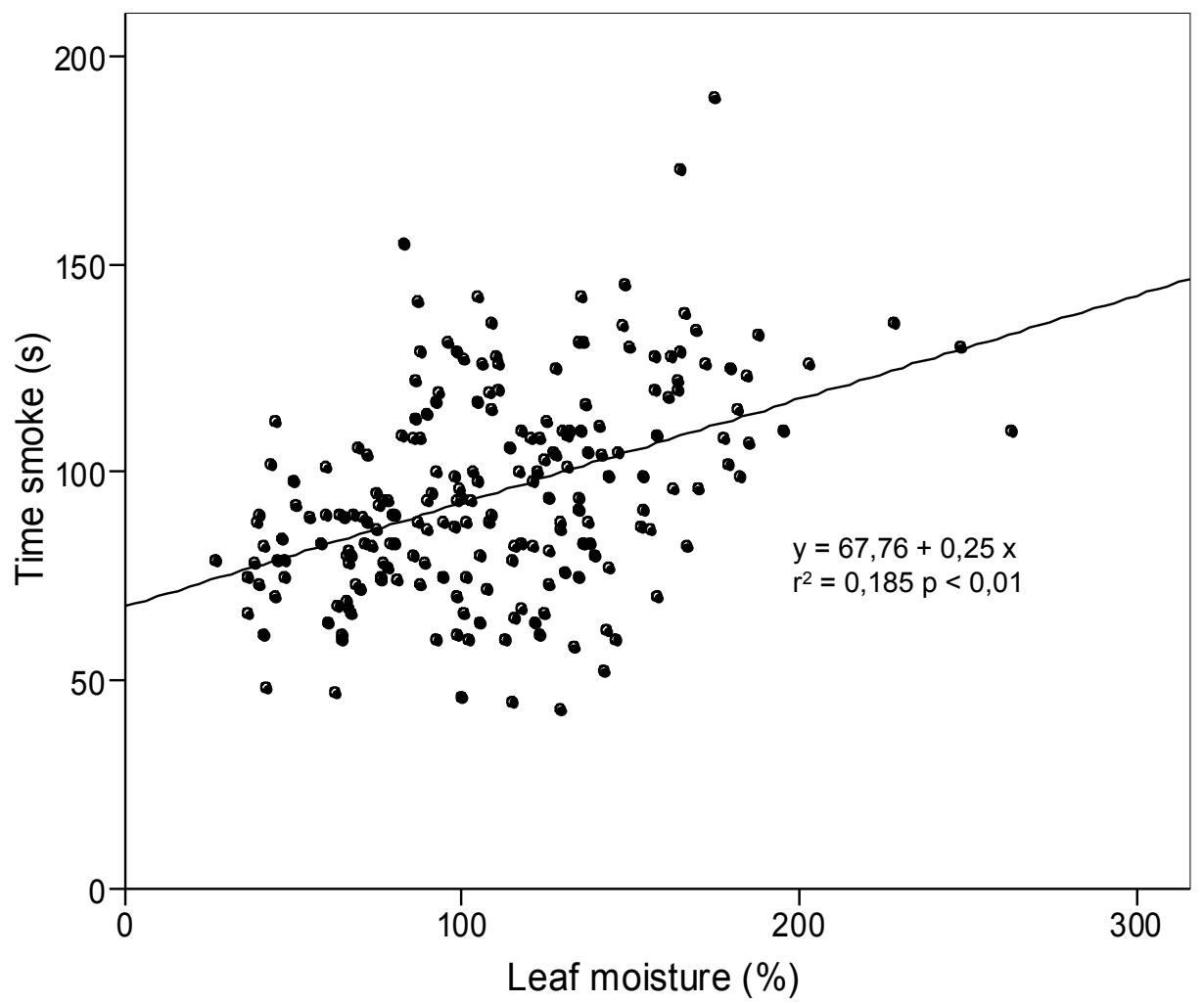

(b)

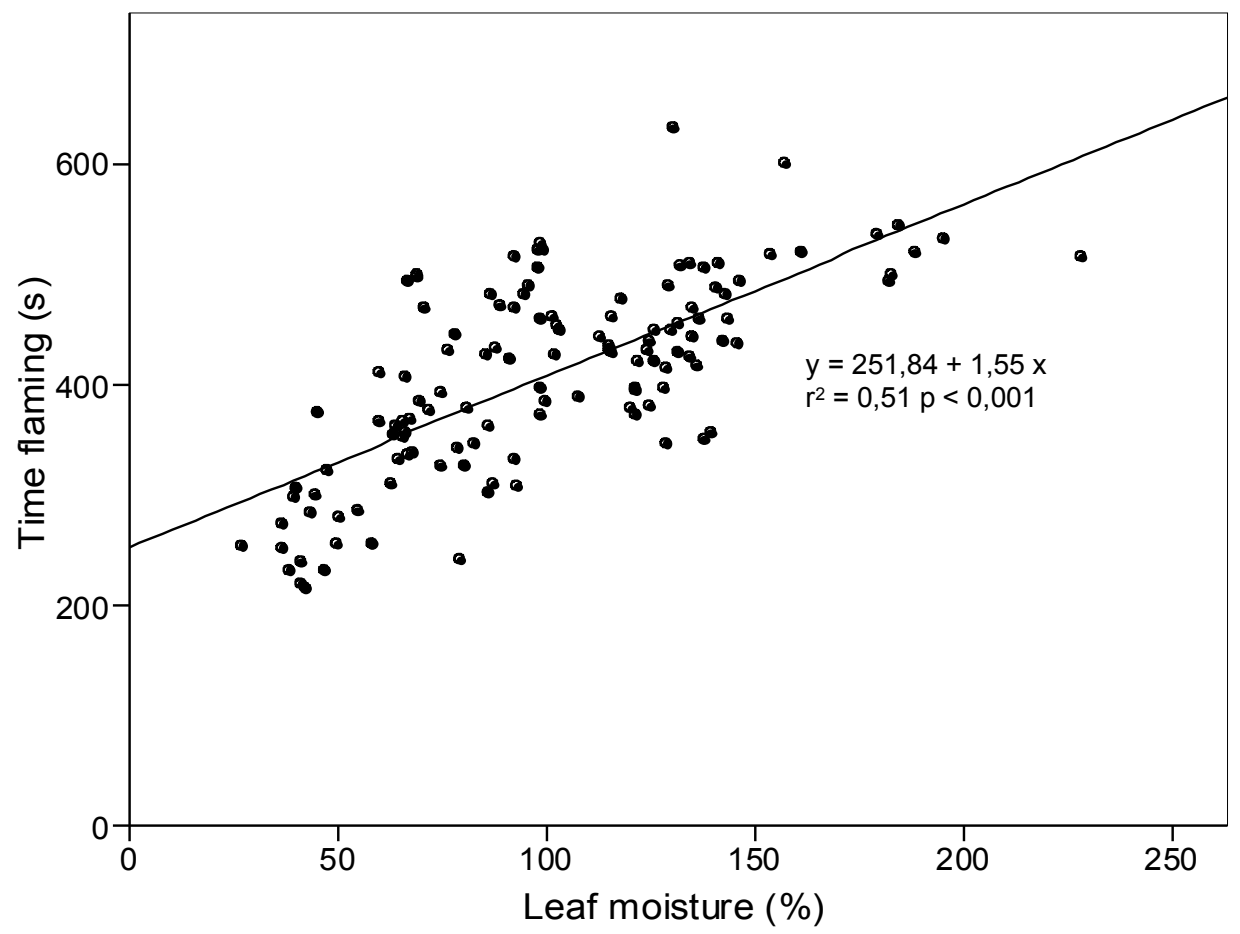


(c)

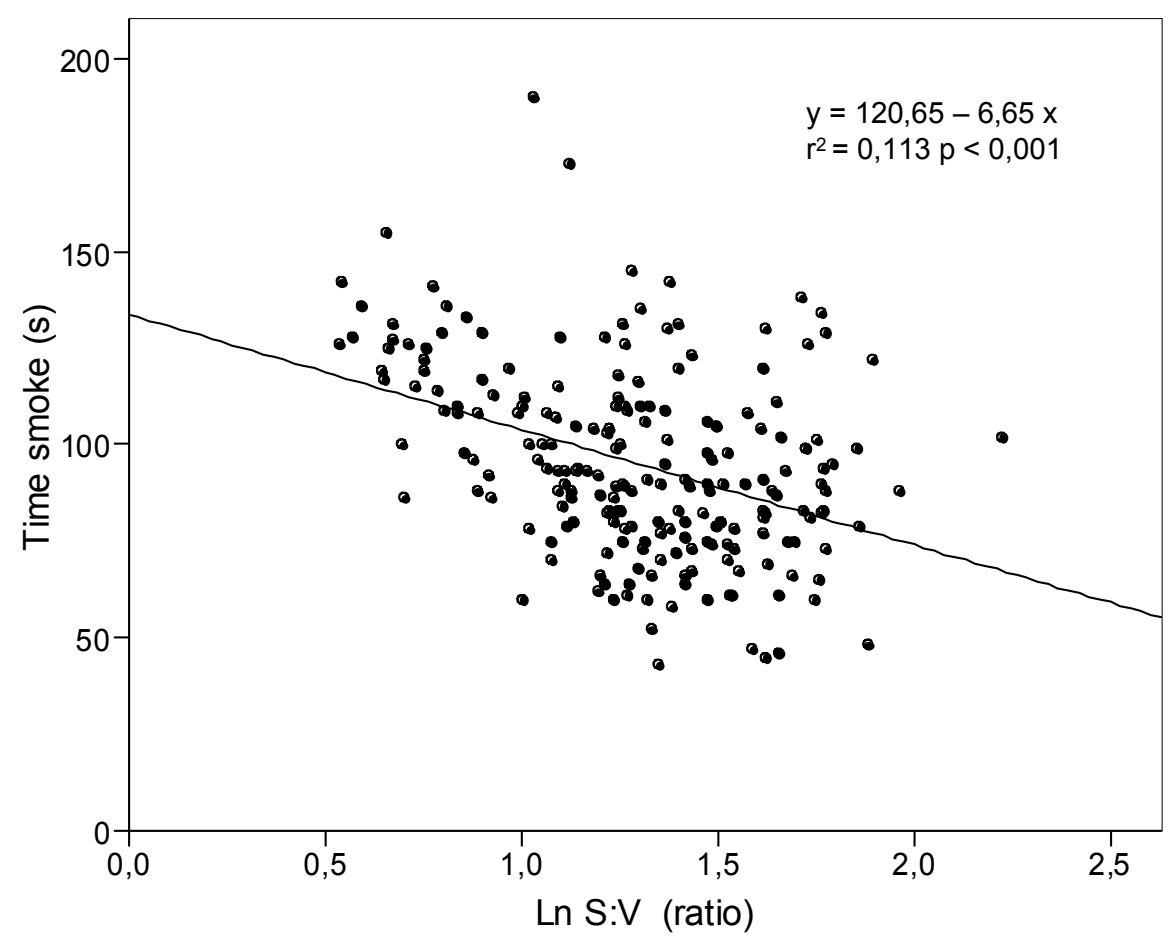

(d)

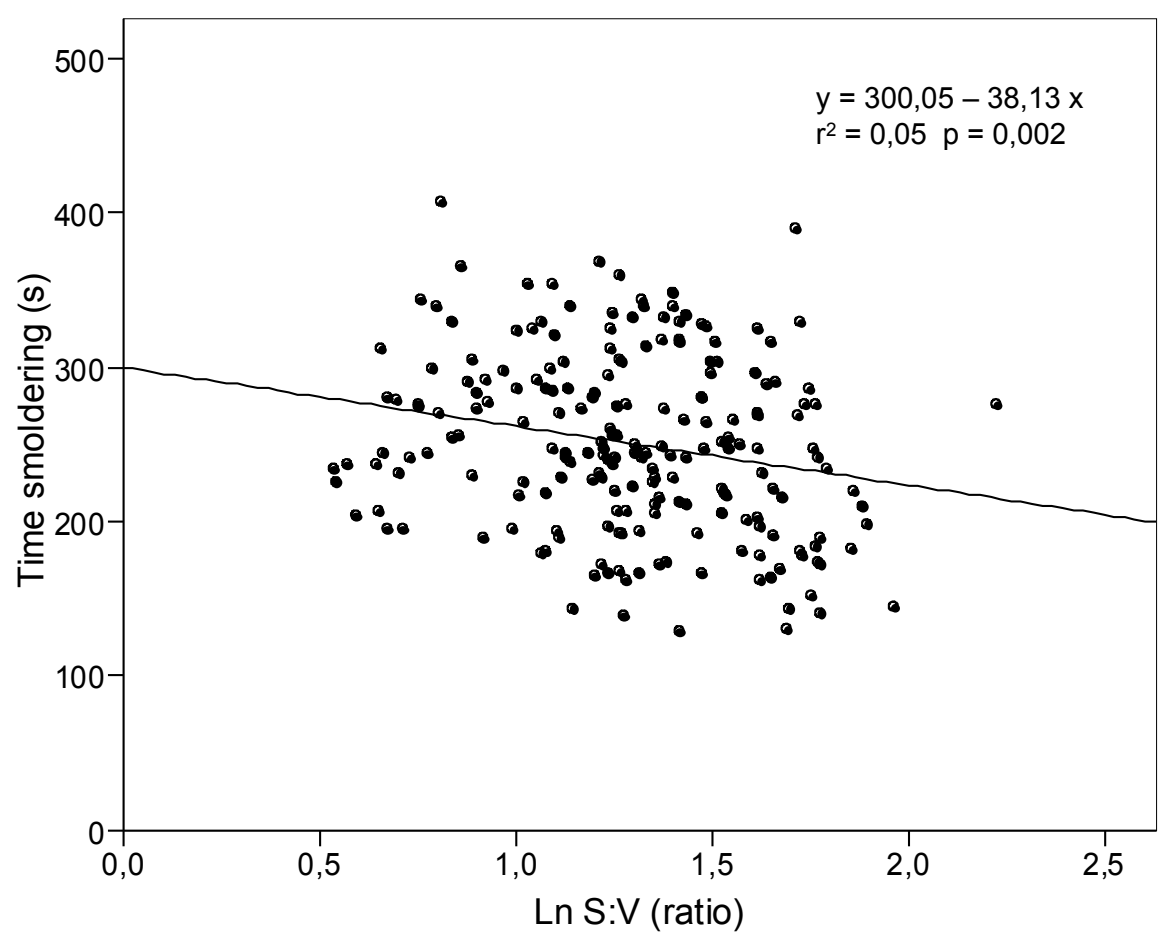


Supplementary material 1. Mean value per species and site (standard error between brackets) of the live and dead fuel relative to the total plant dry mass, separated by fuel diameter and overall mean value. Leaves are included in the live fine-fuel fraction.

\begin{tabular}{|c|c|c|c|c|c|c|c|c|c|c|c|c|}
\hline & \multicolumn{4}{|c|}{ Fine $(<6 \mathrm{~mm})$} & \multicolumn{4}{|c|}{ Coarse $(>6 \mathrm{~mm})$} & \multicolumn{4}{|c|}{ Total } \\
\hline & \multicolumn{2}{|c|}{ Live } & \multicolumn{2}{|c|}{ Dead } & \multicolumn{2}{|c|}{ Live } & \multicolumn{2}{|c|}{ Dead } & \multicolumn{2}{|c|}{ Live } & \multicolumn{2}{|c|}{ Dead } \\
\hline & Montgri & Murta & Montgri & Murta & Montgri & Murta & Montgri & Murta & Montgri & Murta & Montgri & Murta \\
\hline \multicolumn{13}{|l|}{ Seeder } \\
\hline Calicotome spinosa & $0.36(0.05)$ & $0.24(0.01)$ & $0.29(0.04)$ & $0.24(0.02)$ & $0.11(0.08)$ & $0.51(0.01)$ & $0.39(0.07)$ & $0.01(0.003)$ & $0.61(0.07)$ & $0.75(0.02)$ & $0.39(0.07)$ & $0.25(0.02)$ \\
\hline Cistus albidus & $0.44(0.07)$ & $0.46(0.05)$ & $0.18(0.06)$ & $0.18(0.02)$ & $0.31(0.05)$ & $0.35(0.04)$ & $0.07(0.04)$ & $0.02(0.02)$ & $0.75(0.10)$ & $0.80(0.02)$ & $0.25(0.10)$ & $0.20(0.02)$ \\
\hline Cistus monspeliensis & $0.56(0.11)$ & $0.41(0.04)$ & $0.17(0.06)$ & $0.12(0.02)$ & $0.20(0.05)$ & $0.46(0.03)$ & $0.07(0.07)$ & $0.01(0.01)$ & $0.76(0.12)$ & $0.87(0.03)$ & $0.24(0.12)$ & $0.13(0.03)$ \\
\hline Dorycnium hirsutum & $0.88(0.03)$ & & $0.12(0.03)$ & & 0 & & 0 & & $0.88(0.03)$ & & $0.12(0.03)$ & \\
\hline Dorycnium pentaphyllum & $0.74(0.03)$ & & $0.25(0.04)$ & & $0.01(0.01)$ & & 0 & & $0.75(0.04)$ & & $0.25(0.04)$ & \\
\hline Fumana ericoides & $0.88(0.04)$ & $0.89(0.02)$ & $0.11(0.03)$ & $0.11(0.02)$ & $0.01(0.01)$ & 0 & 0 & 0 & $0.89(0.03)$ & $0.89(0.02)$ & $0.11(0.03)$ & $0.11(0.02)$ \\
\hline Fumana laevipes & $0.97(0.01)$ & & $0.03(0.01)$ & & 0 & & 0 & & $0.97(0.01)$ & & $0.03(0.01)$ & \\
\hline Fumana thymifolia & $0.95(0.03)$ & $0.77(0.02)$ & $0.01(0.01)$ & $0.23(0.02)$ & $0.03(0.03)$ & 0 & 0 & 0 & $0.99(0.01)$ & $0.77(0.02)$ & $0.01(0.01)$ & $0.23(0.02)$ \\
\hline Globularia alypum & $0.57(0.09)$ & $0.69(0.02)$ & $0.22(0.05)$ & $0.15(0.01)$ & $0.18(0.03)$ & $0.17(0.03)$ & $0.03(0.02)$ & 0 & $0.75(0.07)$ & $0.85(0.01)$ & $0.25(0.07)$ & $0.15(0.01)$ \\
\hline Helichrysum stoechas & $0.72(0.06)$ & & $0.19(0.04)$ & & $0.08(0.03)$ & & $0.01(0.01)$ & & $0.81(0.05)$ & & $0.19(0.05)$ & \\
\hline Rosmarinus officinalis & $0.48(0.06)$ & $0.52(0.03)$ & $0.12(0.03)$ & $0.05(0.01)$ & $0.38(0.03)$ & $0.44(0.03)$ & $0.01(0.01)$ & 0 & $0.86(0.03)$ & $0.95(0.01)$ & $0.14(0.03)$ & $0.05(0.01)$ \\
\hline Teucrium polium & $0.80(0.05)$ & $0.66(0.05)$ & $0.16(0.04)$ & $0.34(0.05)$ & $0.05(0.02)$ & 0 & 0 & 0 & $0.84(0.04)$ & $0.66(0.05)$ & $0.16(0.04)$ & $0.34(0.05)$ \\
\hline Thymus vulgaris & $0.83(0.03)$ & $0.80(0.04)$ & $0.07(0.04)$ & $0.18(0.03)$ & $0.10(0.02)$ & $0.02(0.02)$ & 0 & 0 & $0.93(0.04)$ & $0.82(0.03)$ & $0.07(0.04)$ & $0.18(0.03)$ \\
\hline \multicolumn{13}{|l|}{ Non-seeder } \\
\hline$\overline{\text { Coronilla minima }}$ & $0.79(0.04)$ & $0.73(0.03)$ & $0.17(0.03)$ & $0.26(0.02)$ & $0.04(0.02)$ & $0.01(0.01)$ & 0 & 0 & $0.83(0.03)$ & $0.74(0.02)$ & $0.17(0.03)$ & $0.26(0.02)$ \\
\hline Daphne gnidium & $0.55(0.09)$ & $0.30(0.07)$ & $0.07(0.03)$ & $0.10(0.02)$ & $0.36(0.06)$ & $0.51(0.04)$ & $0.02(0.01)$ & $0.08(0.04)$ & $0.91(0.04)$ & $0.81(0.06)$ & $0.09(0.04)$ & $0.19(0.06)$ \\
\hline Osyris alba & $0.68(0.06)$ & $0.49(0.01)$ & $0.24(0.05)$ & $0.06(0.01)$ & $0.07(0.05)$ & $0.45(0.01)$ & 0 & 0 & $0.76(0.05)$ & $0.94(0.01)$ & $0.24(0.05)$ & $0.06(0.01)$ \\
\hline Phillyrea angustifolia & $0.39(0.03)$ & $0.47(0.03)$ & $0.03(0.01)$ & $0.09(0.01)$ & $0.57(0.02)$ & $0.44(0.02)$ & $0.01(0.003)$ & $0.003(0.002)$ & $0.96(0.01)$ & $0.90(0.01)$ & $0.04(0.01)$ & $0.10(0.01)$ \\
\hline Pistacia lentiscus & $0.39(0.06)$ & $0.47(0.01)$ & $0.07(0.01)$ & $0.09(0.004)$ & $0.50(0.05)$ & $0.42(0.02)$ & $0.04(0.02)$ & $0.01(0.003)$ & $0.89(0.03)$ & $0.89(0.01)$ & $0.11(0.03)$ & $0.11(0.01)$ \\
\hline Quercus coccifera & $0.50(0.01)$ & & $0.11(0.01)$ & & $0.39(0.01)$ & & 0 & & $0.89(0.01)$ & & $0.11(0.01)$ & \\
\hline Rhamnus alaternus & $0.36(0.05)$ & $0.43(0.03)$ & $0.07(0.02)$ & $0.12(0.01)$ & $0.55(0.04)$ & $0.45(0.02)$ & $0.01(0.01)$ & $0.005(0.003)$ & $0.91(0.03)$ & $0.87(0.02)$ & $0.09(0.03)$ & $0.13(0.02)$ \\
\hline Rhamnus lycioides & & $0.35(0.03)$ & & $0.18(0.02)$ & & $0.40(0.02)$ & & $0.06(0.01)$ & & $0.76(0.03)$ & & $0.24(0.03)$ \\
\hline
\end{tabular}

